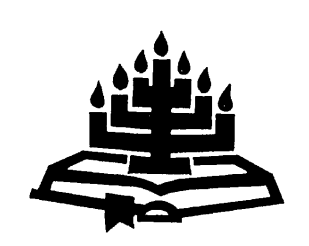

\title{
Sosio-historiese konteks en temas in drie Joodse apokaliptiese geskrifte
}

\author{
M. Nel \\ Departement Ou-Testamentiese Wetenskappe \\ Universiteit van Pretoria \\ PRETORIA \\ E-pos: mariusnel1@mweb.co.za
}

\begin{abstract}
The socio-historical context and themes in three Jewish apocalyptic writings

Exile changed the Jewish world view. Before the exile this world view could be characterised as static and unchanging. However, the orderly world was threatened by powers of chaos, God guaranteed that order would be upheld. During the exile the view originated that history would end in a new future when salvation would come for some Jews. Salvation was regarded as consisting of health, high age and peace. On the basis of this changed world view apocalyptic writings of the third and second centuries $B C$ developed. Apocalyptic literature pretended to reveal the true interpretation of the prophets' message. The assumption was that what happened in heaven determined what would happen on earth. God revealed what was happening in heaven to the apocalypticist. The setting was domination by foreign powers and the wish to be free. Apocalyptic literature was pessimistic about the chances to be saved from the foreign powers of history, and foresaw an end to history and the known world. In the final confrontation God would defeat Satan and his powers and this would lead to the final transformation of the world.
\end{abstract}

\section{Opsomming \\ Sosio-historiese konteks en temas in drie Joodse apokaliptiese geskrifte}

Die ballingskap het die Joodse wêreldbeeld ingrypend verander. Vóór die ballingskap kan dié wêreldbeeld getipeer word as staties en onveranderlik: hoewel die bestaande orde deur chaosmagte bedreig is, het God die voortbestaan van orde gewaarborg. Gedurende die ballingskap ontstaan die gedagte 
dat die geskiedenis op 'n nuwe toekoms sal uitloop wanneer heil vir Jode sal aanbreek. Heil is gedefinieer in terme van gesondheid, hoë ouderdom en vrede. Op grond van hierdie geskrifte groei die apokaliptiese geskrifte van die derde en tweede eeue v.C. Die apokaliptiek gee voor om die egte interpretasie van profetiese idees en geskrifte te wees. Die voorveronderstelling is: wat in die hemel is en gebeur, bepaal wat op aarde gebeur; God openbaar aan die apokaliptikus wat in die hemel is en gebeur. Die omstandighede waarbinne die apokaliptikus optree, was die oorheersing deur vreemde magte en die volk se begeerte om onafhanklik te word. Die apokaliptiek is pessimisties oor die moontlikheid om aan oorheersing te ontsnap binne die geskiedenis, en stel heil uit tot aan die einde van die bekende geskiedenis en wêreld. Dan sal 'n finale konfrontasie aan wanneer God Satan en sy magte sal oorwin en die wêreld finaal sal transformeer.

\section{Inleiding}

Die wêreldbeskouing van die Israeliete in die tydperk vóór die ballingskap het grootliks met dié van die Kanaäniete ooreengestem (Hanson, 1995:11; Nel, 2002a:457). Volgens dié wêreldbeskouing het God die wêreld ordelik gemaak en is dié wêreldorde gereeld bedreig deur faktore soos vloede en droogte, hongersnood en oorloë. Verder is die orde tog gewaarborg omdat God dit bepaal. Ook dra die mens by tot die instandhouding van die orde deur God op 'n voorgeskrewe wyse te dien. Die tempel is gesien as 'n afbeelding van die orde, met sy pilare wat vastigheid simboliseer. Die groot bak met water wat byna helfte van die tempel se vloeroppervlakte opneem, het die oerwater en -chaos uitgebeeld.

In the Near East, the temple had often been seen as a replica of the cosmos. Temple-building had been an act of imitatio dei, enabling humanity to participate in the creativity of the gods themselves (Armstrong, 1993:78).

Deur die voorgeskrewe offers te bring, sou die aanbidder God se hand sterk om orde in stand te hou.

Die verwoestende gevolge van die ballingskapservaring het die wêreldbeskouing van die Jood verander (Cohn, 2001:143): die tempel bestaan nie meer waar offers vir Jahwe gebring kan word nie; die Dawidiese koningsdinastie is vernietig; Jerusalem en die belangrikste stede van Juda is vernietig; groot getalle Jode is in ballingskap weggevoer (Lucas, 2002:37-38; Nel, 2002a:459). Die verandering in die wêreldbeeld van die Jood word onder andere 
deur Esegiël en veral Deuterojesaja verwoord. Een van die belangrikste elemente is dat ' $n$ nuwe wêreld gaan aanbreek wat heil vir (sommige) Jode bring. Heil word gesien as bestaande uit gesondheid, hoë ouderdom en vrede. Die vrederyk sal ook in die natuur neerslag vind. Armstrong (2000:19) verwys na die verwoesting wat die ballingskapservaring in die Joodse lewe indra. Die Jood reageer daarop deur die teks van die Tora as 'n nuwe "tempel" te beskou waarbinne die misplaaste volk 'n bewustheid van die goddelike teenwoordigheid kan vind. "The codification of the world into clean and unclean, sacred and profane objects, had been an imaginative reordering of a shattered world" (Armstrong, 2000:19).

Die teologiese ontwikkelinge ná die ballingskap het die weg berei vir die opkoms van apokaliptiese denke, wat 'n algehele breuk tussen die ou en nuwe wêreld voorsien het - God gaan iets totaal en al nuuts begin (Lucas, 2002:34).

In dié artikel word gekyk na die milieu waarbinne die apokaliptiek ontstaan het voordat enkele eskatologiese aspekte in drie Joodse apokalipse kortliks ondersoek word - Daniël, 1 Henog en Jubileë.

\section{Die Joodse apokaliptiek}

\section{1 'n Nuwe genre: apokaliptiek}

Twee eeue nadat die Persiese ryk die Babiloniese ryk oorweldig het, onderwerp Alexander die Perse. Met sy oorwinning in 334 en 331 v.C. sluit Alexander inderdaad 'n era in die Nabye Ooste se geskiedenis af as hy die Hellenistiese periode in die oostelike Middelandse wêreld inlui. Waar Griekse soldate oorwin, volg koloniste wat stede vestig waarin die Hellenistiese kultuur die oorhand het. Ná Alexander se dood word sy ryk in vier dinastieë verdeel. So beland die derde-eeuse Jode wat na hul land teruggekeer het, hulle onder Ptolemese bewind wat in Egipte gesetel is. Hul provinsie word verdoop na Judaea. Aan die begin van die tweede eeu kom dié provinsie onder Seleukidiese heerskappy, wat in Sirië gesetel was.

Die vroegste Joodse apokaliptiese geskrifte wat bewaar gebly het, dateer uit die derde en tweede eeue v.C. Die beelde hierin is vreemd en anderwêrelds en die simboliek is gesofistikeerd. Daar bestaan nie duidelike bewyse dat die geskrifte vir spesifieke sektes onder die Jode geskryf is nie. Tog het die begrippe in die boeke te doen met chaos en is die bestaande wêreld en die kosmos wat aan 't kom is, vreemd aan die denk- en leefwêreld van die Judeër en 
Jood soos dit sedert die dae van die Deuteronomis ontwikkel het (Zenger, 1998:135-136).

Navorsers noem dié geskrifte apokalipse, omdat dit voorgee om geheime vir 'n uitgesoekte gehoor wat voorheen slegs in die hemel bekend was, bloot te lê. Soms bevat die geheime 'n beskrywing van die hemel(e), maar meer dikwels handel dit oor die lotgevalle van die luisteraars. Trouens, die twee soorte inligting is ten nouste verbind. Wat op aarde gebeur, is hiervolgens slegs 'n afskaduwing en weerspieëling van wat in die hemel gebeur. Die aarde staan op die rand van ' $n$ algehele en finale transformasie, en dit is so omdat dit in die hemel bepaal is.

Die apokalipse is pseudoniem: dit gee voor om in die naam geskryf te wees van 'n heilige persoon wat lank gelede geleef het. Daniël word toegeskryf aan 'n Joodse hofamptenaar uit die sesde eeu v.C. wat tydens die Babiloniese ballingskap geleef het. Jubileë sou deur Moses geskryf gewees het en 1 Henog deur die patriarg wat aan die begin van tyd geleef het. Pseudonimiteit kom gereeld in die Hellenistiese periode voor en word hier as 'n argaïserende stylmiddel gebruik om gesag aan die geskrif te verleen (vgl. Aune, 1983:109 vir ander funksies van apokaliptiese pseudonimiteit). Hiermee word geïmpliseer dat die openbarings van die geskrif ernstig vertolk moet word, want dit is goddelik geïnspireerde uitsprake. Die geskrifte maak daarop aanspraak dat God lank gelede die openbaring gegee het, maar bepaal het dat dit geheim gehou moet word ("verseël") tot die tyd vir die publikasie daarvan ryp is. Die apokaliptici het alles in hul vermoë gedoen om hul werk eg te laat voorkom. Hulle het waarskynlik geglo dat hul werk die Bybelse profesie aanvul en selfs oortref. Russell (1964:158-173) bespreek die gekompliseerde verband tussen Joodse persepsies van tradisie, persoonlikheid en inspirasie. Apokaliptiese teologie gebruik die veronderstelling dat daar agter Bybelse profesieë 'n dieper betekenis lê wat nie deur die profeet self verstaan kon word nie. Dink byvoorbeeld aan Daniël 9 wat aan Jeremia se 70 jaar-profesie 'n nuwe betekenis verleen.

Die apokaliptikus het sy openbarings tot 'n groter mate as die profete in visuele vorm ontvang - deur drome of ekstatiese visioene (Lucas, 2002:35). Soms is die visioenaris na die hemel of die uiteindes van die aarde meegevoer. Wat hy "gesien" het, is in simbole en allegorieë verhul. Die simboliese taal is hoofsaaklik van ou mites afgelei (Hanson, 1995:24). Tot watter mate die apokaliptici werklik visioene gesien het, kan nie meer vasgestel word nie. In die apokaliptiek kom dit tog voor asof die skrywer meer moeite gedoen 
het met sy werk as die profete soos ons hulle uit die Skrif leer ken. Cohn (2001:165) meen dat "it seems inconceivable that without some real, compelling visions the apocalypse would ever have been written down at all".

\subsection{Verskil met profesie}

Apokaliptici se openbarings verskil van profetiese openbarings. Profete het voorsien dat menslike optrede (soos bekering) die gang van die voorspelde toekoms kan verander. Apokaliptici het 'n einde aan die bekende bestel voorsien, en niks wat enige mens doen, kan iets hieraan verander nie (Verhoef, 1993:83). Die toekoms is vooruit bepaal en die afloop is in 'n hemelse boek opgeskryf. Dié afloop sou totaal anders wees as enigiets wat enige klassieke profeet ooit kon voorsien: die aarde sal tot 'n einde kom; alle mense sal tereg staan voor 'n regterstoel waar hulle beloon of vergeld word; party mense sal in engele verander en ander word tot ewige straf verdoem word.

God het direk tot die profete gespreek terwyl die apokaliptikus die openbaring deur 'n bemiddelaar (gewoonlik 'n engel) ontvang het (Vorster, 1986:158-159). Hierdie siening het te doen met die Godsbeeld wat verskuif het sodat Jahwe beskou is as verder verwyder van mense en hul belange. Engele is in die Hebreeuse Bybel bekend, maar word eers in die apokaliptiese geskrifte hoofrolspelers. Hulle bring die visioen, bied die verduideliking daarvoor en waarborg die waarheid en egtheid daarvan. As voorbeeld, vergelyk Daniël 10:4-14. Die verwysing na die Tigris is hier van belang. Die Joodse apokaliptiek verwys terug na Bybelse profesie maar vind 'n verdere wortel in Mesopotamië. Van die tyd van Sumerië af is die ooste bekend vir sy professionele klas van "wyse manne", mense wat in astronomie, meteorologie, geografie en mitiese geografie asook mantiese wysheid (interpretasie van drome) spesialiseer. Die Babiloniese diaspora stel Jode hieraan bloot, en die apokaliptiese genre ontleen veel hieraan (Kvanvig, 1988:189). Daniël en Henog het sterk Babiloniese assosiasies. Die Joodse apokaliptiek maak ook gebruik van antieke Kanaänities-Israelitiese mites. 'n Laaste invloed wat gemeld moet word, is Zoroastranisme (Boyce, 1975: 110-111 en 1982:3-24).

\subsection{Milieu waarbinne die apokaliptiek ontstaan het}

Die milieu waarbinne die apokaliptiek ontstaan het, hou verband met Hellenistiese oorheersing en die gepaardgaande opstandigheid teen die vreemde oorheersers. Hieruit groei pseudonieme profesie wat die val van die buitelandse oorheerser aankondig. In Egipte voorspel 
die "Volkskroniek" en die "Orakel van die Pottebakker" die politieke emansipasie van die Egiptiese volk. Albei geskrifte gee voor om tydens die regerings van lankvergete farao's geskryf te gewees het. Ook die Persiese "Orakel van Histaspes" vertel hoe die oorheerser (hier die Romeinse oorheerser wat die Griekse oorheerser opgevolg het) tot 'n val gaan kom. (In dié geskrifte wend die verowerde volk hom na 'n vergete verlede vir krag om 'n onseker toekoms tegemoet te gaan.) Dié boek word toegeskryf aan Histaspes, wat Zoroaster se beskermheer, Vishtaspa, is. Windisch (1929), Samuel (1970:249254) en Hengel (1974:184-186) bespreek die genoemde tekste en bied vertalings daarvan.

Die Joodse apokalipse dien dieselfde funksie, maar op 'n groter skaal. Die Egiptiese en Persiese orakels handel oor 'n beperkte periode en voorspel beperkte veranderinge, terwyl die Joodse geskrifte die geskiedenis interpreteer, die einde daarvan voorsien en voorspel wat daarna wag. Die profesie ná die ballingskap word tot sy volle konsekwensies deurgetrek: die nuwe wat God gaan bring, behels ' $n$ finale einde aan die ou bedeling.

Die apokaliptiese wêreldbeeld is dualisties en eskatologies (LaCocque, 1988:88): die geskiedenis word geïnterpreteer as 'n stryd tussen goed en kwaad, God en die duiwel met sy magte; die Goddelike bedoeling word deur die loop van die geskiedenis konstant in die wiele gery deur demoniese magte. God gaan egter sy absolute gesag bewys deur die geskiedenis tot 'n einde te bring en die finale, ewige heilseeu te laat aanbreek.

Die vroegste Joodse apokaliptiese geskrif wat in die kanon opgeneem is, dateer uit die krisis van die periode van 160 v.C. Hellenistiese oorheersers het nie in die voorouergodsdiensbeoefening van hul onderdane ingemeng nie. Vir redes waaroor historici verskil, het die Seleukidiese monarg, Antiogos IV Epifanes, wel die beoefening van Judaïsme verbied. Antiogos het die Ptolemeërs in Egipte aangeval, en die Romeine gryp in en stuur hom oneervol huis toe. Waarskynlik het Antiogos 'n ongebalanseerde persoonlikheid gehad. Toe die Jerusalem-hoëpriesterskap in onmin verval, gebruik hy dit as rede om in te gryp. Hy rig die Akra naby die Tempelterrein op wat sy troepe in staat stel om Jerusalem te beheer. Alle onderhouding van die Joodse godsdienstige wet word verbied. In die tempel word die Jahwe-kultus vervang met dié van die Siriese god, Baal Sjamen. Op die nuwe altaar word varke geoffer. 
Israel was 'n gemeenskap wat sy identiteit gevind het in sy ywer vir die Tora. Talle Jode was bereid om vir hul getrouheid daaraan te sterf. Die priesterlike Hasmonese huis het die leiers vir die opstand verskaf, en in 164 v.C. is die tempel bevry.

In die res van die artikel word kortliks na drie apokaliptiese geskrifte gekyk aan die hand van die volgende temas: die vorm van die geskrif; die beskrywing en rol van orde en chaos; die rolspelers; die maatstaf vir 'n goeie lewe, wat die wet is; stryd; en die oordeel en opstanding.

\section{Sommige aspekte van die eskatologie van die Daniëlboek}

\subsection{Inleidende opmerkings}

Die Daniëlboek, die laaste toevoeging tot die Hebreeuse kanon, dateer in sy huidige vorm uit die Antiogeense periode (vgl. Nel, 2002b:1729-1746 vir 'n bespreking van die datering van die boek). Die eerste ses hoofstukke handel oor die wel en wee van Daniël en het moontlik in die Babiloniese diaspora ontstaan. Die verhale is geredigeer om die Jode gedurende die Antiogeense vervolging te bemoedig. Die laaste ses hoofstukke gee voor om deur die sesdeeeuse Daniël geskryf te wees. In vier visioene wat onderling aan mekaar verbind is, word verduidelik wat vir die Jode wag. Die hoofstukke is tussen 169 en 165 v.C. geskryf, waarskynlik deur een skrywer wat ook die verhale oorvertel.

Die visioene beskryf hoe Daniël regkry wat die wyse manne van Babel, die mekka van wysheid, nie kan doen nie, omdat God hom die vermoë gee om drome te interpreteer (Dan. 2). Die vierde koninkryk, verteenwoordig deur die bene van yster en voete van yster en klei, verwys na die troebel verhouding tussen die Seleukiede en Ptolemeërs. Die klip wat die beeld vernietig, is 'n koninkryk wat God aan die einde van hierdie era vestig (Dan. 2:28; 44-45). Dié koninkryk is universeel en ewig. Die Hebreeuse woord vir "ewig" verwys na 'n onbepaalde lang tyd eerder as na die opskorting van tyd, wat 'n Griekse konsep is (Jenni, 1997:853).

Die skema van die vier opeenvolgende ryke is vele kere in die Antieke Nabye Ooste gebruik, maar die Daniëlskrywer gee 'n nuwe betekenis daaraan. Meyer (1921:189-191) en Rowley (1935) het reeds verwys na die gebruik daarvan in die Babiloniese teks bekend as die "Dinastiese Profesie", maar die meeste navorsers twyfel vandag of daar enige direkte verband met die Daniëlboek bestaan. 
Daar bestaan wel 'n treffende ooreenkoms tussen Nebukadnesar se droom in Daniël 2 en die droom wat aan Zoroaster toegeskryf word in twee Pahlavi-kommentare op 'n verlore Avestaanse teks (Lucas, 2002:73). In die droom word vier periodes (nie ryke nie) deur metale gesimboliseer. Die vierde periode, van yster-klei, is die slegste. Die vierde periode eindig 'n duisend jaar ná Zoroaster, wat beteken dat dit die aankoms van die eerste saoshyant aandui (Anklesaria, 1957 bevat 'n vertaling in hoofstukke 1, 3 en 4).

Daniël 7 bied dieselfde interpretasie van geskiedenis as Daniël 2 . Die diere kom uit die see, wat verwys na die ou mite van die see as simbool van chaos wat God vyandig gesind is en die geordende wêreld bedreig. Die vierde dier trek Daniël se aandag. Die verskyning van die horinkie is die teken dat God die geskiedenis tot 'n einde bring. Hy verskyn as "die Oue van Dae". Die titel is afgelei van die Kanaänitiese El wat mettertyd die hoofgod van die Siriese panteon geword het en die eretitel "vader van jare" verwerf het (Armstrong, 1993:22). Hy sit op 'n troon van vuur, geklee in 'n wit kleed, het wit hare en word bedien deur talle howelinge. Die boeke word geopen, die vierde dier word vernietig en sy karkas deur vuur verteer. (Vergelyk ook Ps. 96:12-13; Sag. 14:5 en Joël 3:12.) Dan verskyn "een soos die seun van die mens" uit die wolke van die hemel. Die Oue van Dae gee aan hom soewereiniteit oor alle mense en nasies van die aarde. Alles speel in die hemel af, maar die skrywer dui aan dat dit ook op aarde neerslag vind. Antiogos verteenwoordig die tiende horing asook die horinkie wat geheel en al vernietig gaan word.

\subsection{Orde en chaos}

Die antieke mites oor chaosmonsters was in die tweede eeu v.C. steeds bekend. Die Daniëlskrywer put sy inpirasie hieruit (Collins, 1977:99-104). Die oerwesens verkry nou 'n nuwe betekenis as die verpersoonliking van vreemde oorheersers oor God se volk. Die ooreenkoms lê daarin dat albei God se geordende wêreld bedreig. Hulle poog om orde met chaos te vervang. In Daniël 8 en 11, wat later as Daniël 2 en 7 geskryf is, neem die chaosmonster menslike gestalte aan. Hy plaas die siqus sjomen, 'n duidelike vervorming van baal sjamen, in die heiligdom. So verhef hy homself bo enige god. Maar binne drie en 'n half jaar sal sy koninkryk vernietig word en die tiran sal doodgemaak word.

Die horinkie aspireer om selfs die hemelse leërmag aan te durf en party van hulle, die sterre, op die aarde te werp (Dan. 8:10-11). Sterre en engele is van vroeg af geassosieer. Albei skitter en albei 
word beskou as intelligente en verantwoordelike wesens in diens van die Skepper. Van 169 v.C. af slaan Antiogos munte met sy eie beeld (wat verdag baie na Zeus lyk) en sy titel, "Antiogos Epifanes = god gemanifesteer". Soms is die beeld afgerond met 'n ster (Morkhølm, 1963:63).

\subsection{Rolspelers}

Migael is Israel se beskermengel (Dan. 10:13). Hy is magtig en hy het direkte toegang tot die Een wat op die Troon van Vuur sit. Dit impliseer dat die uitverkore volk wat toe geen politieke mag gehad het nie, nooit deur enige ander nasie vernietig kan word nie. Daarvoor sal Migael sorg. Die beeld wat Daniël 10 skets, kom ooreen met Mesopotamiese mites waar gode teen mekaar veg en die afloop van hul gevegte bepaal wat in oorloë tussen nasies op aarde gebeur. So word die afloop van die Makkabese stryd bepaal deur wat gebeur as die beskermengele van die Grieke en Jode teen mekaar te staan kom (Russell, 1964:244-249).

Wie is "die een soos 'n seun van die mens"? Die frase beteken "een soos 'n menslike wese" of "iemand wat soos 'n mens lyk" en kan bloot verwys na "mens". Waarna die figuur verwys, is vele male bespreek (vir opsommings van die debat, vgl. byvoorbeeld Hartman \& Di Lella, 1978:217; Casey, 1979:141; Lacocque, 1988:214 en Collins, 1993:305). Sommige navorsers sien hierin 'n historiese figuur en dink aan Moses of Judas Makkabeus of Daniël. Daniël 7 bied egter 'n ander prentjie: die seun van die mens ontvang heerskappy, eer en koningskap sodat almal hom dien. Sy regering is vir 'n onbepaalde lang tyd en sal nie ophou nie (Dan. 7:14). Dieselfde word van die heiliges van die Allerhoogste gesê (Dan. 7:18). Die "seun van die mens" verwys dus myns insiens na die heiliges, of in afgeleide sin, na hul verteenwoordiger, wat die beskermengel, Migael, kan wees, of 'n toekomstige "messiaanse" koning. Die "seun van die mens" is simbool van die verkiesing, regverdiging en verhoging van die Jode - of eerder van die klein groep Jode, die elite waarvan die Daniëlskrywer deel is.

Wie is die heiliges van die Allerhoogste? Sommige dink aan die engele (Dequeker, 1960:353-392 en Noth, 1967:215-218). Die meerderheid sien hierin die regverdige Jode (De Boer, 1965:305329). Die korrekte vertaling is "die heiliges van die hoogste een" (Koch, 1980:239). Die belofte in Daniël 7:18 kom ooreen met die frase in Daniël 5:18, waar die heerskappy aan Nebukadnesar oorhandig is. Alles wat voorheen aan heidense supermoondhede behoort het, kom nou die Jode toe. Waar die wêreldmagte mekaar 
opgevolg het, bly die Joodse sonder onderbreking bestaan (vgl. ook Dan. 2:44 en 7:27).

Die heiliges is die Jode wat die leerstellings van "die wyse" volg. "Die wyse" verwys na visioenêre figure soos Daniël en vorm 'n elitegroep. Die groep predik nie-gewelddadige weerstand. Hulle beskou vervolging en verdrukking as die verfyning en suiwering van hul geloof sodat hulle skitterend wit word (Dan. 12:10). Die heiliges gebruik ook 'n eskatologiese interpretasie sodat die Tora in terme van hul eie tyd verstaan word en hulle hul tyd as die eindtyd beleef. Hierdie groep, die heiliges, toon 'n ooreenkoms met die engele wat die heiliges van die hemel is. Die diere is die beliggaming van menslik-politieke mag terwyl dié groep instrumente van goddelike mag is.

\subsection{Stryd}

Die Daniëlboek dien nie die Makkabese ideologie nie en werf nie soldate vir Judas Makkabeus se stryd nie. Dit wil eerder 'n boodskap van bemoediging vir 'n ongeïdentifiseerde groep Jode bring. Die Jode word aangemoedig om getrou te bly aan God ten spyte van die vervolging. Dié tema bind die visioene aan die verhale. God sal sy kinders red as hulle getrou bly. Hy sal die Seleukidiese ryk tot rekenskap roep en straf. Die verloop en uitkoms van die stryd lê buite mense se optrede. Wat in die hemele gebeur, bepaal die afloop.

\subsection{Maatstaf: die wet}

Die nuwe ryk breek op aarde aan. Die begin daarvan word bepaal deur die hertoewyding van die Jerusalemtempel nadat Antiogos dit ontwy het. Tog sal die toekomstige ryk van enige vorige een verskil. Tot op daardie tydstip was geregtigheid slegs in die hemelse heerskappy teenwoordig. Met die aanbreek van die nuwe ryk sal die goddelik bepaalde orde wat in die hemel heers, ook op aarde aanbreek. Die Jode wat in die nuwe ryk heers, verskil ook van hul eweknieë van vorige geslagte: die heiliges van die Allerhoogste sal ten volle sonder sonde wees en met God versoen leef. Hulle sal die Tora toegewyd onderhou, is die veronderstelling.

\subsection{Einde}

Die vestiging van die ryk van die heiliges word voorafgegaan deur 'n goddelike oordeel wat die lot van elke individuele Jood asook die Seleukidiese ryk sal bepaal. Getroue Jode, wie se name opgeskryf 
is in die boek, sal ná die dood van Antiogos van alle verdere lyding gered word. Dit is egter nie al nie. Daniël 12 sluit met 'n profesie dat baie van hulle wat ontslaap het, uit die graf sal opstaan. Party sal ewig lewe terwyl die ander tot ewige skande en veragting veroordeel word (Dan. 12:2). Geen ander gedeelte in die Hebreeuse Bybel kom hiermee ooreen nie. Nickelsburg (1977:18-27) en Johnson (1988: 80-81) bespreek onder andere dié begripsverandering. Die meeste navorsers aanvaar dat Jesaja 26:19 nie vooruitwys na Daniël 12:2 nie.

Wie is die uitgesoekte groep dooies? Menings hieroor verskil. Ek meen die apokaliptikus verwys nie na die hele mensdom en selfs nie na alle Jode nie. Hy voorsien dat twee groepe Jode die dooies vorm wat opgewek word: die martelare wat onder Antiogos se Helleniseringsbeleid getrou aan Jahwe gebly en gesterf het, en die groep Jode wat onder verdrukking geswig en Jahwe versaak het. So spreek die apokaliptikus die teodisee-probleem aan: hoekom sterf die vromes terwyl die ontroues floreer? Hoe kan 'n apostaat (verloënaar van die geloof) met 'n voorspoedige lewe beloon word terwyl die mens wat getrou aan Jahwe bly, wreed sterf? So iets bots met Joodse standaarde van geregtigheid. Daniël 12 word tydens die Antiogeense verdrukking saamgestel en bied 'n oplossing vir die teodisee-vraag wat getroue gelowiges in die oë staar.

Die ontroues se liggame sal blootgestel word sodat die regverdiges hulle kan beswadder, dalk in die Hinnomvallei soos Tritojesaja voorsien. Die martelare lewe vir ewig. Hoe anders kan hulle in die nuwe Joodse wêreldryk deel? In 2 Makkabeërs 14:45-46 word byvoorbeeld verhaal hoe 'n vroom Jood homself met sy swaard deurboor en sy derms oor die toeskouers gooi, eerder as om afgodediens te pleeg. Hy roep uit dat God, die Here van lewe, hom op die regte tyd sy ingewande sal teruggee.

Die bestemming van die "verstandige leiers" is dat hulle soos sterre sal skitter (Dan. 12:3). Moontlik is die taal metafories. Tog dui die koppeling tussen engele en sterre myns insiens eerder daarop dat die apokaliptiek verwag dat die leiers (soos) engele sal word. Die ontwikkeling van Joodse en Christelike apokaliptiek in die volgende drie eeue laat blyk dat heilige individue verwag het om klere van heerlikheid te ontvang wat hulle sal laat skitter. Die apokaliptikus verwag om as 'n superwese voort te leef, soos 'n engel en 'n ster en dat hy/sy met heerlikheid beklee sal word. 


\section{Sommige aspekte van die eskatologie van 1 Henog en Jubileë}

\subsection{Inleidende opmerkings}

1 Henog en Jubileë handel ook oor die goddelik vasgestelde orde en die magte wat dit bedreig. Nie een van die boeke is egter in die Hebreeuse kanon opgeneem nie. Hulle kom nie eens in die lys van apokriewe/ deuterokanonieke boeke voor nie. Tog was die boeke in die eeue voor en na Christus wyd bekend en gebruik.

In die tweede eeue v.C. is ten minste elf manuskripte van 1 Henog by Qumran geproduseer. Die vroeë Christene het die werk graag gelees. Judas (v. 14-15) haal daaruit aan en Barnabas gebruik dit in sy geskrifte in die tweede eeu n.C. asof dit deel van die gesaghebbende geskrifte van die Kerk is. Belangrike vaders soos Klemens van Aleksandrië, Irenaeus en Tertullianus haal daaruit aan. Die boek kom eers in die vierde eeu in Christelike kringe in diskrediet, as gevolg van Hieronimus en Augustinus se standpunt dat die werke nie geskik is vir die opbou van gelowiges nie. Die Oosterse kerk lees tot in die negende eeu n.C. die werk met groot respek. Die Qumranfragmente toon dat die oorspronklike werk hoofsaaklik in Aramees geskryf is. Die hoofbron wat oorgelewer is, is 'n Etiopiese vertaling wat dateer uit die vierde tot sesde eeue. Dié vertaling is vir Etiopiese Christene gemaak. ${ }^{1}$

1 Henog is nie die werk van 'n individu nie, maar 'n versameling werke wat dateer uit die derde eeu v.C. tot die eerste eeu n.C. Dele daarvan het tydens die Antiogeense vervolging ontstaan. Die boek gee egter voor om geskryf te wees deur die sewende aartsvader in die geslagsregister wat van Adam tot Noag gaan. Henog was die pa van Metusalag. Hy was 'n uitsonderlike vroom man. Hy het met God gewandel en toe was hy nie meer daar nie, want God het hom na Hom toe weggeneem (Gen. 5:24).

Dat daar sprake is van die sewende patriarg, toon ooreenkoms met die Sumeriese koningslys wat verwys na die sewende koning asook die sewende Sumeriese wyse, albei figure uit die oergeskiedenis wat steeds 'n rol in die denke van Babiloniërs gespeel het. Die

$1 \quad$ Vir vertalings vergelyk Knibb (1978) en Black (1985). Vir 'n studie van die inhoud kan gekyk word na Milik (1976); McKinney (1976); Hartman (1979); Neugebauer (1981); VanderKam (1984); Uhlig (1984); Barker (1987) en Nickelsburg (2001:81108). 1 Henog, wat soms ook Etiopiese Henog genoem word, moet onderskei word van 'n ander werk wat bekend staan as 2 Henog, Die geheime van Henog of Slawoniese Henog. 
Henoglegende het - nes die Daniëllegende - dan ook in die Oosterse diaspora ontstaan en boots Mesopotamiese modelle na. Teen die tweede eeu v.C. is Henog beskou as 'n superwese met bonatuurlike eienskappe wat direkte kontak met hemelse wesens behou en unieke kennis oor die kosmos en toekoms besit. Jubileë $14: 19,23$ beskryf Henog as die een man wat deur God uitgekies is om die toekoms te sien en te voorspel tot aan die einde van die Laaste Oordeel.

Op die eerste oog af lyk Jubileë soos 'n uitbreiding op die verhaal wat in Genesis en Eksodus van die skepping van die wêreld tot die uittog uit Egipte vertel word. 2 Tog word die verhaal in apokaliptiese vorm gegiet as geheime kennis wat die engele aan Moses op Sinai gee. Ook word die boek deursuur met profesieë oor die groot konsummasie. Die Noagvloed word gesien as 'n voorafskaduwing van die finale ramp.

Jubileë is deur 'n enkele skrywer in $175-140$ v.C. neergepen. Hy maak kwistig gebruik van die ouer gedeeltes van 1 Henog. Die lot van die boek kom ook ooreen met 1 Henog sodat die Etiopiese vertaling die enigste volledige weergawe van die boek is wat bewaar gebly het. Ook Qumran het groot waarde aan die boek geheg sodat die Damaskusdokument dit as gesaghebbend aanhaal en omdat twaalf fragmente daarvan by Qumran ontdek is.

\subsection{Orde en chaos}

1 Henog en Jubileë is produkte van die Hellenistiese wêreld, met 'n wêreldbeeld so ensiklopedies dat dit die geografie van die hemel en aarde, astronomie, meteorologie en geneeskunde insluit. In die oë van 'n Griek, wat trots op sy rasionaliteit was, is die hoogste menslike prestasie om die heelal en die magte wat daaragter sit, ten volle te verstaan.

Because human beings were fallen divinities, the forms of the divine world were within them and could be 'touched' by reason, which was not simply a rational or cerebral activity but an intuitive grasp of the eternal reality within us (met verwysings na Plato; Armstrong, 1993:47).

1 Henog en Jubileë gaan selfs nog verder. Dit wil aantoon dat waar vreemde wysheid te kort skiet, dit nie kennis van die goddelike plan

2 Vertalings van die boek kom voor in Charles (1902) en Charlesworth (1985). Die bespreking daarvan kom onder andere voor in Davenport (1971) en VanderKam (1977). 
kan bied nie. Die apokaliptiese skrywers glo dat hul wysheid meerderwaardig is. "Those works are not so much attempts at imitating Greek wisdom as exercises in emulating and surpassing it" (Cohn, 2001:178).

Die wêreld funksioneer volgens 'n vasgestelde orde. Orde is 'n uitdrukking van God se wil. Hy het alles gemaak en regeer nou soos 'n koning daaroor. Sy troon is die bron van orde, 'n troon van vuur omring met derduisende hemelse wesens wat skitter. In hierdie wêreldbeeld is daar geen ruimte vir onpersoonlike wette nie. Die heelal word regeer deur wette wat deur God bepaal is. Die natuur se reëlmatigheid is 'n bewys van God se orde en die natuur se gehoorsaamheid daaraan. Alles is deur God gemaak en is aan Hom verskuldig om sy bevele en dekrete te gehoorsaam (Limbeck, 1971:64-82).

1 Henog 72-82 bevat 'n reisbeskrywing van die geleentheid toe Uriël Henog deur die heelal neem en beklemtoon die eenvormigheid en orde waarmee en waarvoor God alles geskep het. Alles bly onveranderd tot die nuwe skepping plaasvind - selfs die wind waai in volmaakte balans, 'n illustrasie van die alles-omvattende orde.

\subsection{Rolspelers}

Die engele is verantwoordelik dat die natuur God gehoorsaam. Elke artikel in die wêreld is in die sorg van 'n spesifieke engel geplaas. Engele staan onder die gesag van die Heer van geeste. So het Uriël mag oor die nag en dag om te sorg dat lig op aarde skyn. Hy hou toesig oor die son, maan en sterre (1 Henog 82:8; Jubileë 2:2).

Alle engele is manlik en die twee hoogste groeperinge is deur God besnede geskape. Daarom moet Joodse mans hul ook besny. 'n Seun wat nie op die agste dag besny is nie, behoort van die aarde afgesny te word omdat hy die orde van God bedreig (Jubileë 15:2627). Engele en Jode moet ook die Sabbat en jaarlikse feeste onderhou, en op dieselfde dae.

\subsection{Stryd}

Die geordende wêreld is onvolmaak omdat bose magte daarin aan 't werk is. Hierdie bose magte is daarop gerig om goddelike bedoelings te dwarsboom. Die bose magte tree onafhanklik van God op. In die oud-Israelitiese wêreldbeeld was nie plek vir so 'n begrip nie. Die "teenstander", "aanklaer" of "satan" is 'n engel en raadgewer aan Jahwe se hof wat by geleentheid een of ander mens aankla. Om een voorbeeld te noem: Jubileë 48:3 herskryf die verhaal van 
Eksodus 4:24-25 wat vertel hoe Jahwe poog om Moses te vermoor en hoe 'n vrou sy lewe red. Teen die tyd dat Jubileë ontstaan het, het dit onmoontlik geword om die standpunt te handhaaf dat Jahwe met kwade bedoelings kan optree. Daarom word Jahwe se rol hier vervul deur Mastema, 'n bose gees wie se naam "vyandigheid"' beteken. Mastema is ' $n$ vyand van die Israeliete en bondgenoot van die Egiptenaars en daarom werp hy alles in die stryd om Moses se lewe te neem voor hy sy volk kan gaan verlos. Mastema is die eerste bonatuurlike wese waarvan daar in Joodse literatuur sprake is. $\mathrm{Hy}$ is die personifikasie van vyandigheid teenoor Jahwe en gaan God se bedoeling met sy volk aktief teen. Uit die Jubileë-verwysing groei 'n dualistiese tradisie wat oor tweeduisend jaar die Westerse wêreld se denke sou bepaal.

Prins Mastema tree nie alleen in Jubileë op nie. Hy word deur 'n leër bose magte ondersteun. Wie die demone was en hoe hulle ontstaan, word in die eerste deel van 1 Henog in die Boek van die Wagters vertel (vgl. Bamberger, 1952:19-59 en Forsyth, 1987:160187). Dié inligting word deur Jubileë veronderstel. Die verhaal gryp terug op die Genesis 6-legende en vertel hoe sommige engele deur die mensevroue se skoonheid betower geraak het en met die vroue getrou het. So verbeur hulle hul geestelike vermoëns. Hulle leer mense wat die mens nooit moes geweet het nie: hoe om wapens te vervaardig, verleidelik aan te trek en magie te beoefen (1 Henog 8). Vanweë die gemeenskap tussen engele en mense ontstaan reuse wat alles op aarde verteer, selfs mekaar. Die vermoordes se bloed roep ten hemele sodat die aartsengele by God vir vergelding pleit. Hy antwoord deur die vloed te stuur. Die reuse roei mekaar uit en die gevalle engele word verban om onder die heuwels te bly. Azazel het die mens geleer om wapens te vervaardig en daarom word hy met hande en voete gebind en tot die diepste dieptes van die aarde verban. Alhoewel die engele se liggame opgesluit gehou word, bly hul geeste aktief op die oppervlakte van die aarde. Hulle rig hulle daarop om Jode te verlei om die reinheidswette te oortree en aan heidense gode te offer (1 Henog 15:10-12). In 'n ander tradisie is dit die reuse se geeste wat aktief bly en mense pla en vernietig. Die geeste is die magte wat Mastema se hand sterk maak.

Ná die vloed vind Noag uit dat die geeste wat uit die gevalle engele gebore is, sy kleinkinders op 'n dwaalspoor gelei het en party van hulle doodmaak. In antwoord op sy gebed gee God opdrag dat die aartsengele hierdie geeste of demone binne die aarde opsluit, in die "plek van veroordeling" waar die geeste se vaders reeds is. Maar die demone se leier, Mastema, vra van God die guns dat sommige van die demone op aarde mag bly om onder sy bevel hulle daarop toe te 
lê om mense op 'n dwaalspoor te lei. God laat dit toe omdat Mastema se argument so sterk is dat die mense se boosheid groot is. ' $n$ Tiende van die demone word gespaar tot die oordeelsdag (Jubileë 10:1-9). Van toe af ontplooi Mastema (of Satan of Beliar soos Jubileë ook na hom verwys) sy magte om vernietigingswerk op aarde te doen en mense aan te spoor om bose dade te pleeg (Jubileë 11:2-3).

In die Joodse denke was siekte en sonde altyd verbind. Die demone veroorsaak volgens die nuwe begrip sonde sowel as siekte. Jubileë 10:12 verhaal hoe die aartsengele Noag onderrig in kure vir siektes en dat Noag dit in 'n boek opteken. Sy nageslag baat egter min hierby. Die Jubileë-skrywer is oortuig dat gesondheid en lewenskrag sedert die vloed afneem (Jubileë 23). Aan die begin het mense 'n duisend jaar geleef en sterk gesterf. Later het die lewensverwagting tot 70 of 80 gekrimp en al die dae is met swaarkry gevul. Die rede hiervoor is dat die mens vir sy oortredings gestraf word. Die uiteindelike verantwoordelikheid vir oortredings wat op aarde herhaal word, lê egter nie by die mens nie. Abraham besef dit in Jubileë 12:20 as hy vir beskerming teen Mastema en sy magte bid en sy seun in Jubileë 19:28 seën en vra dat die geeste van Mastema nie oor Jakob sal regeer en hom sodoende van die Here afkeer nie.

God se genade bepaal dat engelewesens gestuur word om mense teen die bose magte se invloed te beskerm. So word die hele wêreld in twee gedeel: God se gehoorsame engele saam met 'n klein minderheid Jode staan teenoor die demone wat die grootste deel van die mensdom in hul mag het. Dié toestand heers tot die "groot oordeel" wat voor hande is. Op daardie tydstip het die kinders grys geword en lyk hulle soos ou mense (Jubileë 23:25). Maar 'n groot verandering lê voor - dit begin met 'n godsdienstige herlewing (Jubileë 23:23). Hierna word die verdrukkers onderwerp. Ook 1 Henog verwys hierna: God kom na die aarde om met sy hemelse magte die vyand te verslaan, sodat hulle geoordeel en gestraf kan word. Jode wat hulle deur die demone laat verlei het, word vir ewig vasgebind en in die Hinnomvallei buite Jerusalem gewerp (Jubileë 22:22).

\subsection{Maatstaf: die wet}

Die "wet van Jahwe" wat hier gebruik word om oor mense se doen en late te oordeel, verskil van die Hebreeuse Tora in dié sin dat sondigheid as onordelikheid of opstand teen God se orde beskryf word. Hierdie wet is immers volgens die voorstelling van die boek 
lank voor Moses aan Henog gegee en geld vir alle mense, nie slegs vir Jode nie.

In Jubileë is die "wet" wel aan Moses geopenbaar, maar die implikasies daarvan gaan verder as die Tora. Die bevele en voorskrifte is op hemelse tablette geskryf en deur 'n engel gepromulgeer. Die "wet" weerspieël ook die goddelik bepaalde orde en sowel Jode as engele moet dit onderhou om God se orde te dien.

Kalenderregulasies word op hemelse tablette opgeteken, maar nie alle Jode onderhou die feeste op die dae soos vasgestel in die hemel nie. Apokaliptici en die Qumrangemeenskap volg die sonkalender, wat met die hemelse sou ooreenkom, teenoor die tempelgemeenskap wat 'n maangebaseerde kalender volg. Die sonkalender was hoogs reëlmatig: elke seisoen van elke jaar begin altyd op 'n Woensdag en die Dag van Versoening en Dag van Pasga val elke jaar op dieselfde dag. Henog het dié kalender uitgevind, volgens dié twee geskrifte. Sy ouderdom van 365 jaar het simboliese betekenis en weerspieël sy uitvinding (Gen. 5:23). Die son bepaal vir Henog die regte volgorde van feesdae en Sabbatte ( 1 Henog 72:35-37 en Jubileë 2:9). Sondaars bereken die dae verkeerd. Uriël beklemtoon vir Moses dat die sonkalender gevolg moet word (Jubileë 6:33). Hy voorsien dat seisoene deurmekaar sal raak omdat onregverdiges die verkeerde kalender volg. En so word heilige dae met "onrein" dae verwar. Mense wat die maankalender volg, versteur die goddelik vasgestelde orde van die kosmos.

In die nuwe wêreld sal slegs die sonkalender gevolg word en slegs mense wat dit onderhou het, staan 'n kans om deel van die geluksalige toekoms te wees.

\subsection{Einde: oordeel en opstanding}

Die einde van tyd sien ' $n$ laaste oordeel. Die maatstaf vir die oordeel is mense se oorgawe aan die goddelike wil om in diens van die orde te staan. 1 Henog 1-5 wat dateer uit die derde eeu v.C. beskryf die oordeel in besonderhede., Binne God se orde is daar vir elke skepsel 'n regte manier om op te tree. Elkeen het 'n rol om te vervul. Deur hierteen in opstand te kom, bring oordeel (Jubileë 5:10, 13; Münchow, 1981:16-64). Soos 'n Nabye Oosterse koning toon God sy mag deur sy vyande genadeloos te straf. As Henog sy reis deur die heelal voltooi, toon Uriël hom die afgrond waar opstandige sterre vir 10000 jaar oor vuur rol omdat hulle nie op voorgeskrewe tye wou "opkom" nie. 
Die gevalle engele wat chaos in die geordende wêreld ingedra het, se straf is verskriklik. Henog sien die woestyn waar hulle gestraf word saam met sterre wat nie op die vasgestelde tyd opgekom het nie. Gevalle engele sal op die oordeelsdag uit hul gevangenis gehaal word om ook hier hul straf te kom uitdien (1 Henog 11).

Dan sal die land skoon wees omdat daar geen bose mag meer sal wees nie (Jubileë 50:5). Die lang proses van degenerasie word omgekeer (Jubileë 23:27-28). Die uitverkorenes leef in vrede omdat die hemelse ligte, wat met nuwe krag aangeraak is, genesend oor die mens skyn. 1 Henog is selfs meer eksplisiet: die uitverkorenes beërwe die aarde en word geseën met voorspoed, vrede en vreugde. ' $n$ Boom wat lewe bring, staan in die midde van die mense en God woon tussen hulle op 'n hoë berg waar sy troon gesetel is en sy lig op alle mense skyn (1 Henog 24-25, 58). Die Diereapokalips van 1 Henog 85-90 vertel dieselfde verhaal aan die hand van die beskrywing van die verskillende nasies as diere en die rol van die bose engele wat as beskermengele van die heidense nasies hulle tot booshede aanspoor. In die Laaste Oordeel word die gevalle engele in die afgrond gestort terwyl die mensdom tydens ' $n$ proses van regenerasie herstel word. Vir die gelowiges wag 'n nuwe Jerusalem met 'n nuwe tempel.

\section{Sintese}

Die apokaliptiek het onder die Jode in die derde en tweede eeue v.C. ontstaan. Die geskrifte se beelde en simbole is vreemd aan die ná-ballingskapse wêreld van die Jood, alhoewel die apokaliptikus die verband nooit volledig verbreek nie. Tradisies wat die godsdiens van Jode tot op datum bepaal het, soos die uittog-, Sions- en Dawidstradisies, geniet nie aandag in apokaliptiese geskrifte nie. Tog word aangesluit by Bybelse profesie. Die apokaliptikus bied sy werk aan as 'n egte, eintlike verduideliking van wat die profete bedoel het.

Die apokaliptiese geskrif is per definisie 'n geheim. Dit verhaal hoe die gebeure in die hemel die gebeure op aarde bepaal. Die geheim bestaan in kennis oor die einde: 'n totale transformasie wag op die aarde. So word die geskiedenis wat ewig volgens antieke Israelitiese denke is, deurbreek.

Die apokaliptikus verskil hierin van sy profetiese eweknie: die profeet sien hoe God in die geskiedenis ingryp en ten gunste van sy volk optree, die apokaliptikus is pessimisties oor die gang van die geskiedenis en voorsien dat 'n einde daaraan gebring word. 
Die milieu waarin die apokaliptiek ontstaan, is oorheersing deur vreemde magte en die gepaardgaande versugting van die onderdrukte volk dat hulle verlos sal word.

Die apokaliptiek het 'n dualistiese wêreldbeeld: God en Satan kom teen mekaar te staan en uit die finale stryd kom 'n nuwe wêreld tot stand.

\section{Geraadpleegde bronne}

ANKLESARIA, B.T. 1957. Zand-ī Vohūman Yasn. Bombay: Motilal Banarsidass.

ARMSTRONG, K. 1993. A history of God. London: Vintage.

ARMSTRONG, K. 2000. The battle for God. Fundamentalism in Judaism, Christianity and Islam. London: HarperCollins.

AUNE, D.E. 1983. Prophecy and early Christianity and the ancient Mediterranean world. Grand Rapids: Eerdmans.

BAMBERGER, B.J. 1952. Fallen angels. Philadelphia: Baker.

BARKER, M. 1987. The Older Testament. The survival of themes from the ancient royal cult in sectarian Judaism and early Christianity. London: SPCK.

BLACK, M. 1985. The Book of Enoch or 1 Enoch: A new English edition with commentary and notes. Leiden: Brill.

BOYCE, M. 1975. A history of Zoroastrianism. Vol. 1. HO 1/8/1/2/2A. Leiden: Brill.

BOYCE, M. 1982. A history of Zoroastrianism. Vol. 2. Leiden: Brill.

CASEY, M. 1979. The son of man: the interpretation and influence on Daniel 7. London: SPCK.

CHARLES, R.H. 1902. The Book of Jubilees, or: The little Genesis. London: SPCK.

CHARLESWORTH, J.H. 1985. The Old Testament pseudepigrapha. Volume 2. Expansions of the Old Testament and legends, wisdom and philosophical literature, prayers, psalms, and odes, fragments of lost Judeo-Hellenistic works. New York: Doubleday.

COHN, N. 2001. Cosmos, chaos \& the world to come. The ancient roots of apocalyptic faith. New Haven/London: Nota Bene.

COLLINS, J.J. 1977. The apocalyptic vision of the book of Daniel. Missoula: Scholars Press.

COLLINS, J.J. 1993. Daniel. A commentary on the Book of Daniel. Hermeneia. Minneapolis: Fortress.

DAVENPORT, G.L. 1971. The eschatology of the Book of Jubilees. Leiden: Brill.

DE BOER, P.A.H., ed. 1965. Oudtestamentische studien. Deel 14, 25, 19401965. Leiden: Brill.

DEQUEKER, L. 1960. Ephemerides Theologicae Lavaniensis. Leuven: Gembloux.

FORSYTH, N. 1987. The old enemy: Satan and the combat myth. Princeton: Princeton University Press.

HANSON, P.D. 1995. Isaiah 40-66. Louisville: John Knox. 
HARTMAN, L.F. \& DI LELLA, A.A. 1978. The Book of Daniel. Manchester: Anchor.

HARTMAN, L. 1979. Asking for a meaning: A study of 1 Enoch 1-5. Lund: LiberLäromedel/Gleerup.

HENGEL, M. 1974. Judaism and Hellenism: Studies in their encounter in Palestine during the early Hellenistic period. Philadelphia: Fortress.

JENNI, E 1997. 'ôlam eternity. (In Jenni, E. \& Westermann, C., eds. Theological lexicon of the Old Testament. Vol. 2. Peabody: Hendrickson. p. 852-862.)

JOHNSON, D.G. 1988. From chaos to restoration. An integrative reading of Isaiah 24-27. Sheffield: JSOT.

KNIBB, M.A. 1978. The Ethiopic Book of Enoch: A new edition in the light of the Aramaic Dead Sea fragments. Vol. 2. Oxford: Clarendon.

KOCH, K. 1980. Das Buch Daniel. Erträge der Forschung. Band 144. Under Mitarbeit von Till Niewisch und Jürgen Tubach. Darmstadt: Wissenschaftliche Buchgesellshaft.

KVANVIG, H.S. 1988. Roots of apocalyptic. The Mesopotamian background of the Enoch figure and of the son of man. Neukirchen-Vluyn: Neukirchener Verlag.

LACOCQUE, A.1988. Daniel and his time. Studies of personalities of the Old Testament. Columbia: University of South Carolina Press.

LIMBECK, M.1971. Die Ordnung des Heils. Untersuchungen zum Gesetzverständnis des Frühjudentums. Düsseldorf: Patmos.

LUCAS, E. C. 2002. Daniel. Apollos Old Testament commentary. Leicester, England : Apollos. Downers Grove: InterVarsity.

McKINNEY, R.W.A., ed. 1976. Creation, Christ and culture. Edinburgh: Clark.

MEYER, E. 1921. Ursprung und Anfänge des Christentums. Die Entwicklung des Judentums und Jesus von Nazaret. Vol. 2. Stuttgart: Cotta.

MILIK, J.T. 1976. The Book of Enoch: Aramaic fragments of Qumran, Cave 4. Ox-ford: Clarendon.

MORKHØLM, O. 1963. Studies in the coinage of Antiochus IV of Syria. Copenhagen: Akademisk Forlag.

MÜNCHOW, C. 1981. Ethik und Eschatologie. Ein Beitrag zum Verständnis der frühjudischen Apokalyptik mit einem Ausblick auf das Neue Testament. Göttingen: Vandenhoeck \& Ruprecht.

NEL, M. 2002a. Die Hellenisties-Romeinse wêreld en die ontstaan van apokaliptiek en gnostisisme. Verbum et Ecclesiae, 23(2):452-467.

NEL, M. 2002b. Die Daniëlboek se twee Sitze im Leben. Hervormde Teologiese Studies, 58(4):1729-1746.

NEUGEBAUER, O. 1981. The astronomical chapters of the Ethiopic Book of Enoch (72-82). Copenhagen: Det Kongelige Danske Videnskabernes Selskab.

NICKELSBURG, G.W.E. 1977. Resurrection, immortality, and eternal life in intertestamental Judaism. Cambridge: Cambridge University Press.

NICKELSBURG, G.W.E. 2001. 1 Enoch: A commentary on the Book of 1 Enoch.

NOTH, M. 1967. The laws of the Pentateuch and other studies. Philadelphia: Fortress.

ROWLEY, H.H. 1935. Darius the Mede and the four world empires in the Book of Daniel: a historical study of contemporary theories. Cardiff: University of Wales Press Board. 
RUSSELL, D.S. 1964. The method and message of Jewish apocalyptic. London: SCM.

SAMUEL, D.H., ed. 1970. Proceedings of the Twelfth International Congress of Papyrology. Toronto: Routledge.

UHLIG, S. 1984. Das äthiopische Henochbuch. Gütersloh: Güterslohen Verlagshaus Gerd Mohn.

VANDERKAM, J.C. 1977. Textual and historical studies in the Book of Jubileës. Missoula: Scholars Press.

VANDERKAM, J.C. 1984. Enoch and the growth of an apocalyptic tradition. Washington, DC: Catholic Biblical Association of America.

VERHOEF, P.A. 1993. Profete en profesie. Kaapstad: Lux Verbi.

VORSTER, W.S. 1986. Tekste met 'n apokaliptiese perspektief. (In Deist, F. \& Vorster, W., red. Woorde wat ver kom. Die literatuur van die Ou Testament. Deel 1. Kaapstad: Tafelberg. p. 158-176.)

WINDISCH, H. 1929. Die Orakel des Hystaspes. Amsterdam: Hertz.

ZENGER, E., ed. 1998. Einleitung in das Alte Testament. Stuttgart: Kohlhammer.

\section{Kernbegrippe:}

apokaliptiek: Daniëlboek, 1 Henog, Jubileë

eindoordeel

engele

\section{Key concepts:}

apocalyptycism: Book of Daniel, 1 Enoch, Jubilees

angels

last judgment 
